УДК 78:378.147.018.43

DOI: 10.37026/2520-6427-2021-107-3-146-149
Володимир ОНИЩУК,

старший викладач кафедри естрадної музики Інституту мистеитв Рівненського державного гуманітарного університету, м. Рівне, Украӥна

ORCID: 0000-0002-1073-5364

e-mail: onyshchuk.v.i@ukr.net

\title{
ВПЛИВ НЕФОРМАЛЬНОЇ ОСВІТИ НА ФОРМУВАННЯ ОСОБИСТОСТІ СТУДЕНТА МИСТЕЦЬКОГО ЗАКЛАДУ ВИЩОЇ ОСВІТИ
}

\begin{abstract}
Анотація. У статті розглядаються деякі аспекти неформальної мистецьккої освіти. Доведено, щзо розвиток неформальної мистецьької освіти спричинили певні проблеми формальної вищої освіти, серед яких підготовка фахівиів за застарілими спеціальностяли, комериіалізація вищої освіти, застаріла матеріально-технічна база, яку важко підлаштувати до рівня сучасних інформачійних технологій тощьо.

Доведено, шзо неформальна освіта є найбільш гнучкою, різноманітною за формою $і$ багатоаспектною ланкою системи безперервної освіти, зокрема і мистецьккӧ̈, найприйнятнішим форматом якоі є онлайн-формат. Можливості, які пропонує інтернет, надають нову додаткову иінність навчанню
\end{abstract}

за допомогою різних методів подання інформачії, поєднання різних видів контенту (аудіо- та відеофайлів, презентаиій тощь). Вебсайти і сторінки в соціальних мережах, які дозволяють здобувачам освіти демонструвати власні мистеиькі досягнення, дискутувати стосовно них, мотивують молодих людей приймати креативні рішення, творчо розвиватися, а також праиюють як самоорганізоване поле для мистеиької освіти у ї̈ кращих проявах. Обтрунтовано, щуо сучасна мистеиька освіта має бути якісною та доступною $i$ забезпечуватися ефективним поєднанням формальної та неформальної освіти.

Ключові слова: неформальна освіта, мистецька освіта, дистаниійне навчання, інтернет, молодь.

\author{
Volodymyr ONYSHCHUK, \\ Senior Lecture of the \\ Department of Popular Music, \\ Rivne State Humanitarian University, \\ Rivne, Ukraine \\ ORCID: 0000-0002-1073-5364 \\ e-mail: onyshchuk.v.i@ukr.net
}

\section{THE INFLUENCE OF NON-FORMAL EDUCATION ON THE FORMATION OF STUDENT'S PERSONALITY OF HIGHER EDUCATION ART INSTITUTION}

\begin{abstract}
The article considers some aspects of informal art education in the context of the development of the Internet and various relevant communities. The term «informal education» the author refers to any systematized knowledge and competencies acquired outside the system of formal education. It is noted that the development of informal art education has caused problems of formal higher education - training of specialists in obsolete specialties, commercialization of higher education, outdated material and technical base, which does not correspond to the level of modern information technologies and so on.

The inflexibility and backwardness of the formal higher education system became noticeable during the quarantine period of 2020-2021, when the unpreparedness of free educational institutions to work remotely became clear, and young people found that education could be obtained independently without leaving home.

The author is convinced that informal education is the most flexible, diverse in form and multifaceted part of the
\end{abstract}

system of continuing art education, the most acceptable format of which is the online format. Network technologies add new added value to learning through different styles of presenting information, combining different types of content (audio, video files, presentations, etc.).

Websites and social media pages that allow young people to showcase their artistic achievements, discuss them, motivate young people to make certain artistic decisions, develop creatively, and work as a self-organized field for art education at its best. It is indicated that modern art education should be high quality and accessible and provided with an effective system of formal and informal education.

Key word: informal education, art education, distance learning, internet, youth.

Постановка проблеми. Сучасна українська система вищої освіти як фактор культурного відтворення відчуває неабиякі труднощі, пов'язані з протиріччями між 
виробниками і споживачами освітніх послуг. Серед них варто виокремити такі: заклади вищої освіти (далi-3BO) готують кадри за застарілими спеціальностями для ресурсозатратної економіки минулого; комерціалізація вищої освіти не дає можливості її отримати здібним молодим людям із незабезпечених сімей; застаріла матеріально-технічна база закладів вищої освіти не відповідає рівневі сучасних інформаційних технологій та ін.

Недосконалість, негнучкість та відсталість системи вищої освіти особливо стала помітною в період карантину, спричиненого пандемією COVID-19, адже саме кризові ситуації демонструють слабкі місця будьякої системи. 3 одного боку, чітко проявилася неготовність ЗВО працювати дистанційно, а з іншого більшість молодих людей з'ясували, що освіту можна здобувати й самостійно, не виходячи 3 дому. Випускники шкіл усе частіше відмовляються від навчання в університетах заради швидких і сучасних альтернатив. Експерти також вважають, що освітня система, що склалася в індустріальну епоху, вже не задовольняє запити сучасної економіки, яка потребує кадрів, які пройшли швидке навчання (Крикуненко, 2019).

Аналіз наукових досліджень і публікацій. Теоретичною основою для обгрунтування положень, висвітлених у статті, є роботи науковців А. Журкіної, М. Коваль, Н. Ничкало, О. Огієнко, Л. Сігаєвої та ін. щодо пошуків альтернативи вищій освіті в Україні та світі. Дослідження неформальної освіти студентської молоді відображено в працях вітчизняних дослідників Ю. Деркач, Л. Шаповалової О. Бондаренка, П. Кряжева. Питання мистецької неформальної освіти висвітлено в наукових розвідках М. Лещенко, Н. Сулаєвої, О. Аніщенко та ін.

Мета статті - дослідити сучасні тенденції надання неформальних освітніх послуг та їхній вплив на формування особистості студентів мистецьких закладів вищої освіти.

Виклад основного матеріалу. Поняття «неформальна освіта» увійшло в обіг у кінці 60 -х років XX століття. Так, у 1967 році під час Міжнародної конференції в Вільямсбурзі (США) постало питання щодо світової освітньої кризи у зв'язку з проблемою із застарілими навчальними програмами та низькою здатністю формальної освіти адаптуватися до глобальних змін. Стало очевидним, що отримати всі необхідні знання тільки в системі офіційної освіти неможливо, а на зміну застарілій концепції «одна освіта на все життя» прийшла інша - «навчання протягом усього життя» (lifelong education). Саме тоді й з'явився поділ на формальну, інформальну і неформальну освіту.

Формальна освіта - це освіта, що здобувається відповідно до освітніх ліцензованих програм закладів освіти і передбачає досягнення здобувачами освіти заздалегідь визначених результатів навчання. Форми цього виду освіти - очне та заочне навчання в закладах освіти різних рівнів акредитації.

Інформальна освіта (самоосвіта) - це освіта, яка передбачає самоорганізоване здобуття особою певних компетентностей, зокрема під час повсякденної діяльності, пов'язаної із професійною, громадською або іншою діяльністю, родиною чи дозвіллям. Формами інформальної освіти є одноразові лекції, відеоуроки, медіаконсультації, спілкування з родиною та колегами, читання спеціалізованих журналів, телебачення, відео, незаплановані випадкові бесіди тощо.

Неформальна освіта - це будь-які систематизовані знання та компетенції, що набуваються поза системою формальної освіти. На відміну від формальної, такий вид освіти не обов'язково підтверджується дипломом або будь-яким іншим документом про їі отримання, відповідно установи, що займаються неформальною освітою, не зобов'язані мати державні ліцензії на ведення програм і курсів. Формами неформальної освіти є очна (тренінги, майстер-класи, семінари, майстерні тощо) та дистанційна (дистанційні курси, вебінари).

Неформальна освіта має систематичний, але не повсякденний характер. Хоча існують установи, створені тільки для здійснення даного виду освіти, неформальна освіта не є монополією навчальних закладів. Вона здійснюється в різних економічних, суспільних і політичних установах. Методи навчання за таких умов носять новаторський характер, а цілі ставляться практичні й нагальні, відповідні індивідуальним навчальним потребам і першочерговим завданням суспільного розвитку. Неформальна освіта користується неабиякою свободою щодо змісту, методів і форм навчання. Обирається вона, як правило, без координації з уже існуючими програмами, а отже, являє собою не пов'язану систему, а швидше своєрідну «мозаїку», різні елементи якої можуть не тільки заміняти один одного, а й вступати в протиріччя.

У зв'язку з цим очевидно, що неформальна освіта $є$ найбільш гнучкою, різноманітною за формою і багатоаспектною ланкою системи безперервної освіти, зокрема й мистецької. Вона неабияк здатна задовольнити освітні потреби зацікавлених груп населення, адже пов'язана з їхнім професійним зростанням; відзначається нетрадиційним підходом до організації навчально-пізнавальної діяльності, тісним зв'язком із сучасним соціокультурним середовищем, усебічним стимулюванням самоосвіти, самовиховання і саморозвитку людини, незалежно від ії̈ віку, місця проживання, але обов'язково з урахуванням ії освітніх потреб та інтересів (Аніщенко, 2016, с. 5).

Якщо говорити про вплив неформальної мистецької освіти на покращення навчального процесу, то варто наголосити, що вона $є$ не лише вагомим інструментом покращення навчального процесу, оскільки саме мистецтво допомагає створити комфортне середовище для щасливого життя людини, а й інформаційно збагачує та дає змогу трансформувати набуті знання, погляди, а також ефективно впливає на творчий розвиток особистості загалом (Лещенко, Сулаєва, 2017, с. 33).

Неформальній освіті, особливо мистецькій, притаманна неабияка ефективність, що обумовлена:

- високим ступенем мотивації, адже спонукальні причини до продовження навчання зосереджені не так у зовнішніх примусових умовах, як у внутрішніх імпульсах людини;

- цілеспрямованістю, усвідомленням навчальної діяльності молодої людини, що базується передусім на самостійному навчанні;

- цілями навчання;

- гнучкістю, необхідною для задоволення різноманітних індивідуальних потреб молоді через ви- 
користання аудіо- та відеозасобів, друкованої продукції як варіативних форм зв'язку з нею;

- відносно невисокою платою за навчання (порівняно зі школами, 3ВО тощо) чи відсутністю плати взагалі;

- гнучкою системою фінансування (Дубасенюк, Самойленко, 2020, с. 184).

Неформальна мистецька освіта в Україні переживає сьогодні своєрідний «бум». Так, заповнюючи прогалини у формальній освіті, почали з'являтися неформальні музичні освітні проєкти, адже реформування середньої і вищої школи - надзвичайно громіздкий і тривалий у часі проєкт, тоді як неформальна мистецька освіта - більш гнучка, легше адаптується до нововведень, а іноді й сама $є$ їхнім «провідником». Оскільки ми живемо в епоху утвердження ери цифрової цивілізації, для якої характерні зміни можливостей і засобів навчання мистецтву, зокрема й музичному, то логічним $\epsilon$ те, що і розвиток неформальної освіти активніше просувається саме в інтернеті. Експерти припускають, що впродовж найближчих десяти років неформальна онлайн-освіта і професійні висококонцентровані школи неабияк потіснять формальну вищу освіту: 3-поміж 280 університетів у країні залишиться (в кращому разі!) - половина (Крикуненко, 2019).

Фундаментальні принципи неформальної музичної освіти - доступність і добровільність. Поєднання із концепцією «навчання протягом усього життя» робить неформальну музичну освіту оптимальним інструментом для музикантів з абсолютно різними цілями - від заповнення прогалин у базовій музичній освіті до підвищення рівня знань для професійної діяльності.

Практично все навчання, яке не призводить безпосередньо до отримання диплома, можна вважати неформальною освітою. Ї̈ї цільовою аудиторією може бути будь-хто: діти і дорослі, люди з музичною освітою і без неї. На сьогодні в мережі «Інтернет» накопичилася величезна кількість навчальних відео- та аудіокурсів, які дозволяють вивчати музичне мистецтво, не виходячи $з$ дому. Перевагами таких форм освіти є свобода вибору (ніхто не нав'язує програму, затверджену незрозуміло ким, не тисне); наочність (онлайн-курси містять у собі ту ж інформацію, що й очне навчання, але подача - наочна, а отже, інформація значно краще і швидше сприймається - за кілька хвилин можна засвоїти те, що доведеться вивчати пів години); економія (займаючись самоосвітою за допомогою інтернету, можна зекономити на репетиторах, послуги яких, як відомо, недешеві, а також на часі - не витрачати чотири роки на опанування професією, яка після закінчення навчального курсу може виявитися незатребуваною на сучасному ринку праці).

Таким чином, упродовж навчання в університеті молоді люди можуть опанувати декілька професій i чимало навчитися. Для нового покоління чотири роки величезний термін. Крім того, сучасні діти народилися в середовищі медіакультури, а отже, вони не можуть відокремити їі від інших сфер свого життя, як це можуть зробити дорослі.

В Україні щороку ринок онлайн-освіти зростає на $5 \%$, відповідно зростає й попит на різноманітні платформи та спільноти з музичними освітніми кур- сами і лекціями (як платними, так і безкоштовними). Саме вони стали однією з популярних альтернатив університетським заняттям. Ще однією стороною в неформальній освіті $є$ ті, хто викладає. Стейкхолдерами (зацікавленими особами) неформальної музичної освіти, крім молоді, є сотні викладачів, які після роботи в університетських аудиторіях підпрацьовують у «третіх місцях» (коворкінг, навчальні центри тощо), викладаючи цікавий матеріал та нестандартно його подаючи.

Інтернет пропонує значну кількість матеріалу, придатного і для викладання музики, і для навчання молоді. Наприклад, на сайті Wholenote.com $є$ майже три тисячі уроків гри на гітарі. Крім того, сайт пропонує ентузіастам, які цікавляться цим інструментом, чимало практичного матеріалу. На думку дослідників, саме онлайн-формат найкраще підходить для неформальної музичної освіти. Технології мережі надають нову додаткову цінність музичному навчанню за допомогою різних стилів подання інформації, поєднання різних видів контенту (аудіо- та відеофайли, презентації тощо). Вебсайти і сторінки в соціальних мережах, які дозволяють молодим людям пропагувати власну музику чи дискутувати стосовно неї, мотивують їх приймати певні музичні рішення, творчо розвиватися, а також працюють як самоорганізоване поле для музичної освіти у іiі кращих проявах (Salavuo, Myllykoski, 2006, с. 217-218).

У музичних спільнотах мережі «Інтернет» молодь об'єднується з ентузіастами, які поділяють ії музичні та соціальні цілі. Так, популярна фінська музична спільнота Mikseri.net налічує близько 60 тис. зареєстрованих користувачів, які не лише оприлюднюють власну музику, а й коментують творчість інших людей. Це надзвичайно важливо для творчої мотивації: молоді люди бачать, скільки разів їхня музика обговорювалася чи прослуховувалася людьми по всій країні або навіть в усьому світі. За допомогою цієї чи подібних спільнот (наприклад, SoundClik.com, GarageBand.com, PureVolume.com та ін.) кожен, хто володіє музичними технологіями і має мережеве 3'єднання, може оприлюднити власну музику і її почують в усьому світі, тобто нові технології дозволили поширювати музичні твори високого рівня у невеличких домашніх студіях iз низькими експлуатаційними витратами.

Разом із тим, використання інтернету для неформальної музичної освіти вимагає як певної функціональної технічної інфраструктури, так і певного рівня технічних можливостей, а також відповідних навичок інформаційного пошуку з боку користувача.

Висновки. Без сумніву, сучасні освітні технології неабияк впливають на навчання студентів мистецьких спеціальностей. Значну роль у цьому процесі відіграє неформальна освіта, зосереджена передусім у мережі «Інтернет». В інтернет-спільнотах прості рішення, додатки, послуги та інструменти все більше використовуються не для комерції, а для підтримки інформації, обміну нею, навчання та загального користування. Блоги, подкасти та різні науково-дослідницькі й навчальні спільноти стають важливою частиною навчального середовища.

Неформальна освіта є своєрідним додатком, альтернативою, доповненням до освіти формальної, адже дозволяє людині навчатися протягом усього життя. 
Вона поступово перетворюється на джерело розвитку компетентності сучасної молоді та стає важливою складовою її музичного навчання, адже молоді люди бажають концентруватися на освіті поза межами навчального закладу. Значення неформальної освіти для особистості студентів мистецьких спеціальностей визначається її цілями, як-от: розвиток навичок критичного мислення, самосвідомості та самостійності; створення умов для розкриття себе, своїх талантів і можливостей; допомога у формуванні власного світогляду. Саме неформальна освіта дає можливість пізнавати, формувати власну позицію щодо навколишньої дійсності, дозволяє залучати молодь у різні форми соціальної активності.

Основною проблемою неформальної освіти в Україні є передусім невизнання іiі державою як ефективної альтернативи та доповнення до формальної освіти; низька взаємодія з інституціями формальної освіти - школами, коледжами, університетами; відсутність постійних майданчиків, освітніх платформ для взаємодії та розвитку неформальних освітніх послуг.

Неформальна освіта може максимально ефективно доповнити освіту формальну своєю практичністю, гнучкістю, швидкістю отримання результатів та спрямованістю на розвиток індивідуальності.

Перспективами подальших досліджень у даному напрямі є подальше дослідження значення неформальної освіти у підготовці майбутніх фахівців-музикантів.

\section{СПИСОК ВИКОРИСТАНОЇ ЛІТЕРАТУРИ}

Крикуненко, I. (2019). Університетський бунт. Чому вища освіта втрачає привабливість. НВ [Новое время]. URL: https://nv.ua/ukr/biz/economics/vishchaosvita-yaki-korektivi-v-neji-vnosit-rinok-praci-noviniukrajini-50040117.html/ (дата звернення: 12.02.2021).

Аніщенко, О. (2016). Неформальна мистецька освіта дорослих у контексті культурноосвітнього простору регіону. Культурно-мистеиьке середовище: творчість та технології: матеріали IX Міжнародної наук.-творч. конф. (м. Київ, 21 квітня 2016 р.). Київ: НАКККіМ. С. 3-5.

Лещенко, М., Сулаєва, Н. (2017). Досвід організації неформальної мистецької освіти у світовому педагогічному просторі. Ukrainian professional education. Вип. 1. С. 31-37.

Дубасенюк, О. А., Самойленко, О. А. (2020). Основи андрагогіки (для фахівців у галузі освіти дорослих): навч.-метод. посіб. Житомир: ЖДУ ім. І. Франка. 175 с.

Salavuo, M., Myllykoski, M. (2006). World Wide Web musiikin oppimisympäristönä. Musiikkikasvatusteknologia. Suomen musiikkikasvatusteknologian seura. Keuruu: Otava.

\section{REFERENCES}

Krykunenko, I. (2019). Universytetskyi bunt. Chomu vyshcha osvita vtrachaie pryvablyvist [University riot. Why higher education is losing its appeal]. $N V$ [Novoe vremia]. URL: https://nv.ua/ukr/biz/economics/vishchaosvita-yaki-korektivi-v-neji-vnosit-rinok-praci-noviniukrajini-50040117.html/ (data zvernennia: 12.02.2021). [in Ukrainian].

Anishchenko, O. (2016). Neformalna mystetska osvita doroslykh u konteksti kulturnoosvitnoho prostoru rehionu [The nonformal artistic education of adults in the context of cultural space in the region]. Kulturno-mystetske seredovyshche: tvorchist ta tekhnolohii: materialy IX Mizhnarodnoi nauk.-tvorch. konf. (m. Kyiv, 21 kvitnia 2016 r.). Kyiv: NAKKKiM. S. 3-5. [in Ukrainian].

Leshchenko, M., Sulaieva, N. (2017). Dosvid orhanizatsii neformalnoi mystetskoi osvity u svitovomu pedahohichnomu prostori [Experience in organizing nonformal art education in the world pedagogical space]. Ukrainian professional education. Vyp. 1. S. 31-37. [in Ukrainian].

Dubaseniuk, O. A., Samoilenko, O. A. (2020). Osnovy andrahohiky (dlia fakhivtsiv u haluzi osvity doroslykh) [Fundamentals of andragogy (for professionals in adult education)]: navch.-metod. posib. Zhytomyr: ZhDU im. I. Franka. 175 s. [in Ukrainian].

Salavuo, M., Myllykoski, M. (2006). World Wide Web musiikin oppimisympäristönä [World Wide Web as a learning environment]. Musiikkikasvatusteknologia. Suomen musiikkikasvatusteknologian seura. Keuruu: Otava. [in Finnish].

Дата надходження до редакиії: 20.04.2021 p. 